\title{
Jean-Baptiste Sarlandière's Mechanical Leeches (1817-1825): An Early Response in the Netherlands to a Shortage of Leeches
}

\author{
TEUNIS WILLEM VAN HEININGEN*
}

\section{Introduction}

At the end of the eighteenth century there was a rapidly growing demand for leeches in Europe. Western European and Central European freshwater species had been mainly used until then but now more and more different species were introduced. ${ }^{1}$ England imported large numbers from Eastern Europe and the Levant, and Pondicherry in Southern India was an important centre for the shipment of these animals whose application was considered a mild form of bloodletting. ${ }^{2}$ In the autumn of 1825 the Algemeene Konsten Letterbode, a Dutch weekly journal, drew attention to a shortage, informing its readers that large numbers, kept for medical purposes, had died without an apparent cause, ${ }^{3}$ possibly through an unknown infective agent. It also printed information by a German pharmacist from Kassel on the proper method of keeping leeches alive as long as possible in large aquaria, by including water plants. ${ }^{4}$

One solution to the problem had already been invented-the artificial leech of JeanBaptiste Sarlandière. At their annual general meeting, held on 21 May 1821, the officers of the Dutch Society of Sciences (Hollandsche Maatschappij der Wetenschappen, founded in 1752), on learning of Sarlandière's invention through Martinus van Marum, the Society's secretary, decided to hold a competition on its serviceability. ${ }^{5}$ They were persuaded by the increasing demand for leeches, as well as by the fascinating and promising aspects and originality of Sarlandière's invention. At the time, the Dutch Society of Sciences was one of the leading scientific societies in the world with a long and reputable tradition in the fields of science and technology. Through the annual programme,

(C) Teunis Willem van Heiningen 2009

* Teunis Willem van Heiningen, MSc, PhD, Diepenbrocklaan 11, $7582 \mathrm{CX}$, Losser, The Netherlands, e-mail: heinluit@hetnet.nl

\footnotetext{
${ }^{1}$ Initially Hirudo medicinalis (or "German Leech") and Hirudo officinalis (or "Hungarian Leech") were used.

${ }^{2}$ Roy T Sawyer, 'The trade in medicinal leeches in the Southern Indian Ocean in the nineteenth century', Med. Hist.,1999, 43: 241-5.

${ }^{3}$ Algemeene Konst- en Letterbode, Haarlem, Loosjes, 1825, 2: 158.

${ }^{4}$ For similar advice, see, for example, J L Derheims, Histoire naturelle et médicale des sangsues, contenant la description anatomique des
}

organes de la sangsue officinale..., Paris, J-B Baillière, 1825, pp. 155-65; Joseph Martin, Histoire pratique des sangsues; organisation de ces animaux, espèces et variétés, etc., Paris, Panckoucke, 1845, pp. 29-47, 51, 67-87, 99; Louis Vayson, Guide pratique des éleveurs de sangsues, Paris,

J-B Baillière, 1852, pp. 128-38. It refers to Bulletin de l'Académie de Médecine de Paris, February 1848, pp. $613 \mathrm{ff}$. On p. 660 the conclusions of a report on an investigation regarding the shortage of leeches are given. These conclusions were accepted unanimously.

${ }^{5}$ Martinus van Marum (1750-1837), renowned physicist, chemist and botanist, Fellow of the Royal Society (London) and of several other learned societies; in 1794 he was made secretary for life of the Dutch Society of Sciences, and he was Director of Teylers Museum (Haarlem). 


\section{Teunis Willem van Heiningen}

which was translated into French before being sent to the many foreign members of the Society, as well as to the various affiliated scientific societies like those of London, Paris, Edinburgh, Vienna, Berlin, St Petersburg, Turin and Washington, Sarlandière was informed about the contest involving his bdellometre or artificial leech, as he called it. ${ }^{6}$ However, it was probably not until early 1825 that he decided to enter this competition.

\section{Jean-Baptiste Sarlandière}

Jean-Baptiste Sarlandière was born in Aachen on 9 May 1787 into a family of physicians, so from his earliest years he was familiar with the medical profession. At the age of sixteen he became a chirurgien-sous-aide at the hospital on the island of Noirmoutier, west of Bordeaux. In 1803 he interrupted his training for eleven years of service in the French army, being dismissed in 1814 when the monarchy returned to France. Thereupon he left for Paris in order to complete his defective medical education, after which he was employed at the military hospital, the Val-de-Grâce. In June 1815 he took his doctor's degree in Paris with a dissertation entitled Effets des cosmétiques chez les dames. He made friends with François Magendie, who inspired him to take an interest in physiology and took him on as his assistant. ${ }^{7}$ They collaborated in a series of physiological experiments. Sarlandière soon built up a flourishing practice in which he focused on the treatment of rheumatic and nervous disorders, making successful use of electricity, acupuncture and electroacupuncture (introduced by him to European medicine). ${ }^{8}$ His wide reputation is shown by the fact that, on 10 November 1827, Isaac Titsingh, at the time leader of the Dutch delegation in Japan and founder of Japanese studies in the Netherlands, sent him a letter to which he had added the Dutch translation of a Japanese manuscript, discussing the practice of acupuncture and the application of moxa. Sarlandière's book on this subject was published in Paris in 1825. His Anatomie méthodique, ou Organographie humaine and his Physiologie de l'action musculaire appliquée aux arts d'imitation were published in 1830.

At the time the Dutch Society of Sciences held its competiton on the bdellometre, Sarlandière was already a docteur en médecine at the Val-de-Grâce hospital. Besides, he was a member of the Société Médicale d'Emulation of Paris, the Société Royale de Médecine of Madrid, the Société de Médecine of Louvain, and the Imperial Academy of Sciences of St Petersburg. He was also a Chevalier d'Honneur de la Première Classe du Royaume de Prusse. Sarlandière died in Paris in July 1838, leaving an unfinished Traité du système nerveux.

\footnotetext{
${ }^{6}$ In his brochure on the bdellomettre (1819) Sarlandière explains: " $\beta \delta \varepsilon \lambda \lambda \omega$ " means "I inhale" and " $\mu \varepsilon \tau \rho o \nu$ " means "to measure"; Vivian Nutton tells me that : " $\beta \delta \varepsilon \lambda \lambda \alpha$ " or " $\beta \delta \varepsilon \lambda \lambda$ on" means "leech".

${ }^{7}$ François Magendie (1783-1855), anatomist, pioneer in experimental (neuro)physiology, held the chair of medicine at the Collège de France (Paris) from 1830 to 1855 .

${ }^{8}$ Jean-Baptiste Sarlandière, Mémoires sur l'électro-puncture, considéré comme moyen nouveau
}

de traiter efficacement la goutte, les rhumatismes et les affections nerveuses, et sur l'emploi du moxa japonais en France; suivi d'un traité de l'acupuncture et du moxa, Paris, J-B Sarlandière et Mlle Delaunay, 1825; Biographisches Lexikon der hervorragenden Ärzte aller Zeiten und Völker, Berlin and Vienna, Urban \& Schwarzenberg, 1929-1935, vol. 5, pp. 23-4. 
Jean-Baptiste Sarlandière's Mechanical Leeches

Table 1

Leech imports and consumption in France, and exports of leeches from France between 1827 and 1836

\begin{tabular}{llclr}
\hline Year & Number of leeches Imported & Value (Francs) & National consumption & Exports \\
\hline 1827 & $33,653,694$ & $1,009,611$ & $33,456,744$ & 196,950 \\
1828 & $26,981,900$ & 809,457 & $26,689,100$ & 292,800 \\
1829 & $44,573,754$ & $1,337,212$ & $44,069,848$ & 503,906 \\
1830 & $35,485,000$ & $1,064,550$ & $34,745,848$ & 739,250 \\
1831 & $36,487,975$ & $1,094,639$ & $35,245,875$ & $1,242,100$ \\
1832 & $57,487,000$ & $1,724,610$ & $55,591,700$ & $1,895,300$ \\
1833 & $41,654,300$ & $1,249,629$ & $40,785,650$ & 868,650 \\
1834 & $21,885,965$ & 656,579 & $21,006,865$ & 879,100 \\
1835 & $22,560,440$ & 676,813 & $21,323,910$ & $1,236,530$ \\
1836 & $19,736,800$ & 592,104 & $18,721,555$ & $1,015,245$ \\
\hline
\end{tabular}

Alexandre E Baudrimont, Adolphe J Blanqui, et al., Dictionnaire de l'industrie manufacturière, commerciale et agricole, Paris, J-B Baillière, 1833-1841, pp. 25-30.

\section{The Invention of the Bdellomètre}

In 1817 Sarlandière invented a mechanical blood pump, intended to produce a controlled evacuation of blood from the human body. In 1819 he published the description of this device, his bdellometre, in a pamphlet. ${ }^{9}$ In it he argued that the application of leeches caused several inconveniences, which did not occur with the use of ventouses or bleeding cups. He had already decided several years earlier to replace leeches, which had become more and more scarce, and as a result more and more expensive. He calculated that more than 1.5 million francs a year was spent on leeches in hospitals throughout France. The information given in Table 1 refers only to the official French imports of leeches carried out under the surveillance of the customs agencies. Additional sources of leeches were an illegal import trade, and large-scale domestic leech cultivation projects, technological aspects of which were discussed in manuals published in France after 1815.

The increasing consumption inevitably led to a disastrous shortage of leeches, although several large-scale breeding and acclimatization experiments were carried out. Initially, pressure of work kept Sarlandière from designing his bdellomètre, which he had envisaged several years earlier. Not until 1817-when he was still working as a military physician-did he have the opportunity to realize his plans and to show his design to several physicians, in particular to François Broussais, at the time assistant professor of medicine at the Val-de-Grâce. Between 1829 and 1832 Broussais was at the pinnacle of his fame. In his view every disease found its origin in an over-stimulation of the body by external influences, expressing itself through hyperaemia and inflammation. He prescribed the application of large numbers of leeches in order to reduce over-stimulation and its secondary effects on the body. Broussais soon received the nickname "le vampire de la médecine". ${ }^{10}$

\footnotetext{
${ }^{9}$ Jean-Baptiste Sarlandière, Bdellomètre $d u$ Docteur Sarlandière, Paris, Firmin Didot le jeune, 1819.
}

\footnotetext{
${ }^{10}$ François Joseph Victor Broussais (1772-1838). Marie-Luce Jardin, Les Thérapies par les sangsues: les pratiques les plus anciennes aux traitements
} 


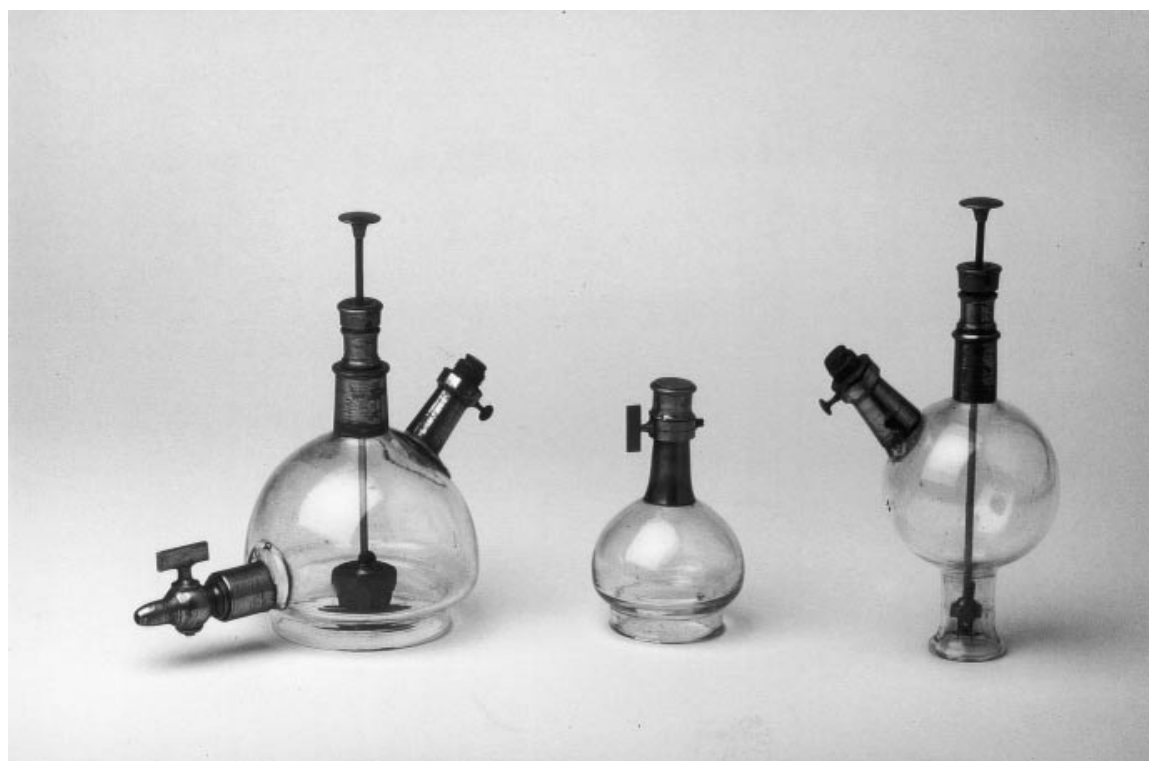

Figure 1: Bdellomètres designed by Jean-Baptiste Sarlandière, 1817-19, in the collection of the Museum of the History of Medicine of Paris, Universite' René Descartes (12, Rue de l'École de Médecine, Paris, France). Photograph reproduced by kind permission of the Museum.

However his popularity did not outlive the end of 1832, when an epidemic of cholera infested France and neighbouring countries. Although Broussais tried to conceal the ineffectiveness of his therapy, the death of his most important patient, Casimir Périer, prime minister under Louis-Philippe, discredited his theory. ${ }^{11}$ Thanks to Broussais's influence (he not only promoted the use of leeches but also bloodletting) France soon became the largest consumer of leeches in the civilized world.

In June 1818 Sarlandière showed his drawings to an instrument maker, who referred him to the firm of Dumotiez, engineers to the Académie Royale des Sciences. ${ }^{12}$ In January 1819, when the design was complete to his satisfaction, he informed Broussais, who saddled him with a certain Dr Bernard, who shortly intended to leave for New Orleans. He wished to take a prototype of Sarlandière's bdellomètre with him. ${ }^{13}$ After

actuels hautement scientifiques, Université de Franche-Comté, Faculté de Médecine et de Pharmacie de Besançon, 2005, Thèse, pp. 32-3.

${ }^{11} \mathrm{G}$ Canguilhem, Idéologie et rationalité dans l'histoire des sciences de la vie, Paris, J Vrin, 1977, pp. 60-1.

${ }^{12}$ Sarlandière made his first arrangements with Louis-Joseph Dumotiez and his brother Pierre-François Dumotiez, physical instument makers and "ingénieurs de l'Académie Royale de Médecine" (Paris).

${ }^{13}$ Sarlandière, op. cit., note 9 above, 'Pièces justificatives', p. 17: this is not the same Bernard as that mentioned in note 37 ; for the increasing demand of leeches in North America, see Stephen L Adams, 'The medical leech: historical perspectives', Seminars in Thrombosis and Hemostasis, 1989, 15 (3): 261-4. The practice of bloodletting increased in popularity from the late 1700 s to the mid-1800s and so did the use of leeches. At one time it was estimated that the United States imported many millions annually from Europe for medical purposes; John C Hartnett, 'The care and use of medicinal leeches', Pharmacy in History, 1972, 14: 127-38. In 1833, physicians in Philadelphia used leeches caught locally, while New York and Boston importers supplied pharmacists with foreign leeches. 


\section{Jean-Baptiste Sarlandière's Mechanical Leeches}

having shown Bernard his design, Sarlandière invited him to accompany him on a visit to Dumotiez, who had already agreed to make the instrument. The Paris faience manufacturer Acloque, who had been asked by Dumotiez to blow the glass bells, handed this commission on to the only glassworks in Paris which was able to produce these bells (cloches, ventouses or glass cupping devices). Dumotiez then produced the first prototype of the bdellometre in its various versions, agreeing that these instruments would be given to Dr Bernard. When in June 1819 Sarlandière decided to order the production of a second series of instruments, meant for Dr Pierre Lortet of Lyons, ${ }^{14}$ Dumotiez and Sarlandière discovered that a couple of cloches were missing. Only then did Sarlandière learn that, although they were not complete, his instruments had been shown at the meetings of several medical societies, without any mention of their inventor's name. It appeared that his instrument had been built secretly by Nicolas-Constant Pixi-Dumotiez, the nephew of the former owners. ${ }^{15}$ He also learned that it had been demonstrated for the first time on 18 May 1819, at a meeting of the Société Académique de Médecine in Paris. The fact that someone else had appropriated the credit finally spurred Sarlandière to claim his rights, and to publish the complete design and description of his instrument. At the same time he decided to keep all relevant items under lock and key. All in all he was quite certain that nobody had outdone him. The only person who might dispute his invention was Antoine-Pierre Demours, ${ }^{16}$ although Sarlandière was convinced that he would be able to refute any possible claim. ${ }^{17}$ Meanwhile his bdellometre had been tested in several hospitals, and Broussais and Jean-Baptiste Regnault spoke highly of it. ${ }^{18}$

In another pamphlet, produced in 1819, Sarlandière once more listed the reasons why he had had his instrument manufactured. Many countries were deficient in leeches; several used scarificators, followed by the application of ventouses. In the case of capillary bloodletting this method did not produce the anticipated results. Besides, the use of these instruments was laborious and inconvenient in many respects. Because during recent years the theory of inflammation had made tremendous progress and the use of leeches in French hospitals had expanded enormously, the administration of these hospitals was confronted with a considerable increase in the price of this treatment. Many patients preferred bloodletting by means of a lancet to the bite of leeches because they had an unconquerable aversion to these animals. Physicians and surgeons, while going on their rounds in the country, did not usually have leeches among their equipment. Therefore, there is no doubt that they needed an instrument with which capillary bloodletting could be carried out easily. Most importantly, after the application of a certain number of leeches it was never

\footnotetext{
${ }^{14}$ Pierre Lortet (1792-1868), physician and politician; from 1836 he held the position of governor of the hospitals of Lyons.

${ }^{15}$ In 1815 Nicolas-Constant Pixi-Dumotiez (1776-1861) took over the firm owned by his uncles.

${ }^{16}$ Antoine-Pierre Demours (1762-1836) was an anatomist, surgeon and leading ophthalmologist in Paris. He was the son of Pierre Demours (1702-1795), ophthalmologist (Paris).

${ }^{17}$ Sarlandière, op. cit., note 9 above, 'Pièces justificatives', p. 19.
}

\footnotetext{
${ }^{18}$ Ibid., pp. 15, 17; Antonius Gerardus van Onsenoort, Operatieve Heelkunde, 2nd ed., Amsterdam, 1836-1837 (first edition, 1822), vol. 1 p. 171. Van Onsenoort (1782-1841) had a career in military medicine. In 1811 he was appointed surgeonmajor in the French southern army. He became surgeon at the military hospital of Leuven (Belgium) in 1815 , and, in 1817 , first officer of the military Health Service of the Netherlands (Leuven). He taught theoretical and practical surgery and ophthalmology, and ended his career teaching at the Central Military Hospital of Utrecht.
} 


\section{Teunis Willem van Heiningen}

possible to determine exactly how much blood had been evacuated. It was also impossible to evaluate the rate of the flow of blood. Some leeches were very active while others fell off before they became even one quarter full. Since leeches differed in size, it was clearly impossible to measure the effect of this remedy.

For all these reasons, Sarlandière decided that he had to design an instrument which could imitate leeches in their operation and with which it was possible to adjust the velocity and quantity of blood to be discharged. The instrument should also be constructed in such a manner that the treatment could be carried out easily. In Sarlandière's view his own design met exactly with all these criteria.

Sarlandière opened his brochure on the bdellomètre by announcing that he had improved his instrument so much that there was nothing left to be desired. ${ }^{19}$ In his view, the latest version of this perfect instrument offered more advantages than the ventouses used until then. It was provided with three tubes, as shown in Figure 1 (on the left) and in Figure 2 (on the right). It enabled physicians to carry out capillary bloodlettings on any surface of the body. This model had a wide and rather short neck, with which capillary discharges of the blood under vacuum could be carried out on flat surfaces and on slightly curved ones, like the abdominal wall, the breast and the thigh. A second model had a longer and narrower neck (Figure 1, on the right; Figure 2, object marked fig. 2). It was meant for smaller surfaces, such as the temporal region, for encircling small tumours or for carrying out a puncture.

After Sarlandière had designed these instruments, he learned that Pierre Lortet wanted to improve his instrument, especially with regard to capillary bloodlettings in mucous membranes. Together they decided to solve this technical problem. They designed a third model (Figure 2, y, z), a tubular instrument of at least three inches long, whose conical and bent end could easily be put in the nose, mouth, vagina and rectum. The lower end of the silver rod, contained in the centre of the tube, bore a bundle of stiff pig's bristles. In order to create a vacuum, this tubular instrument had to be adjusted to the upper central glass tube of the bdellometre. With the bdellometre, wounds could be made so quickly that the patient had no time to feel the pain.

Sarlandière ended his pamphlet by observing that the complete instrument, together with all its accessories was available for the price of 80 francs at Dumotiez's (instrument makers to the Académie des Sciences, 31 Rue Capeau, Paris). That same year his bdellometre was shown at the Exposition de l'Industrie in the Louvre Museum. ${ }^{20}$

\section{Operating the Bdellomètre}

In the two larger versions of Sarlandière's instrument represented in Figure 2, the lower end of the rod, enclosed in the central tube, bears a grid through which its sharp lancets can be adjusted at various heights. This rod can be moved upwards and downwards in the central tube through a diaphragm of superposed leather plates, which are

\footnotetext{
${ }^{19}$ Sarlandière, op. cit., note 9 above, 'Avertissement', p. 21. du Louvre, Paris, 1819, pp. 195 ff. It was numbered 1122 .

${ }^{20}$ Rapport du jury d'admission des produits de l'industrie du Département de la Seine à l'Exposition
} 


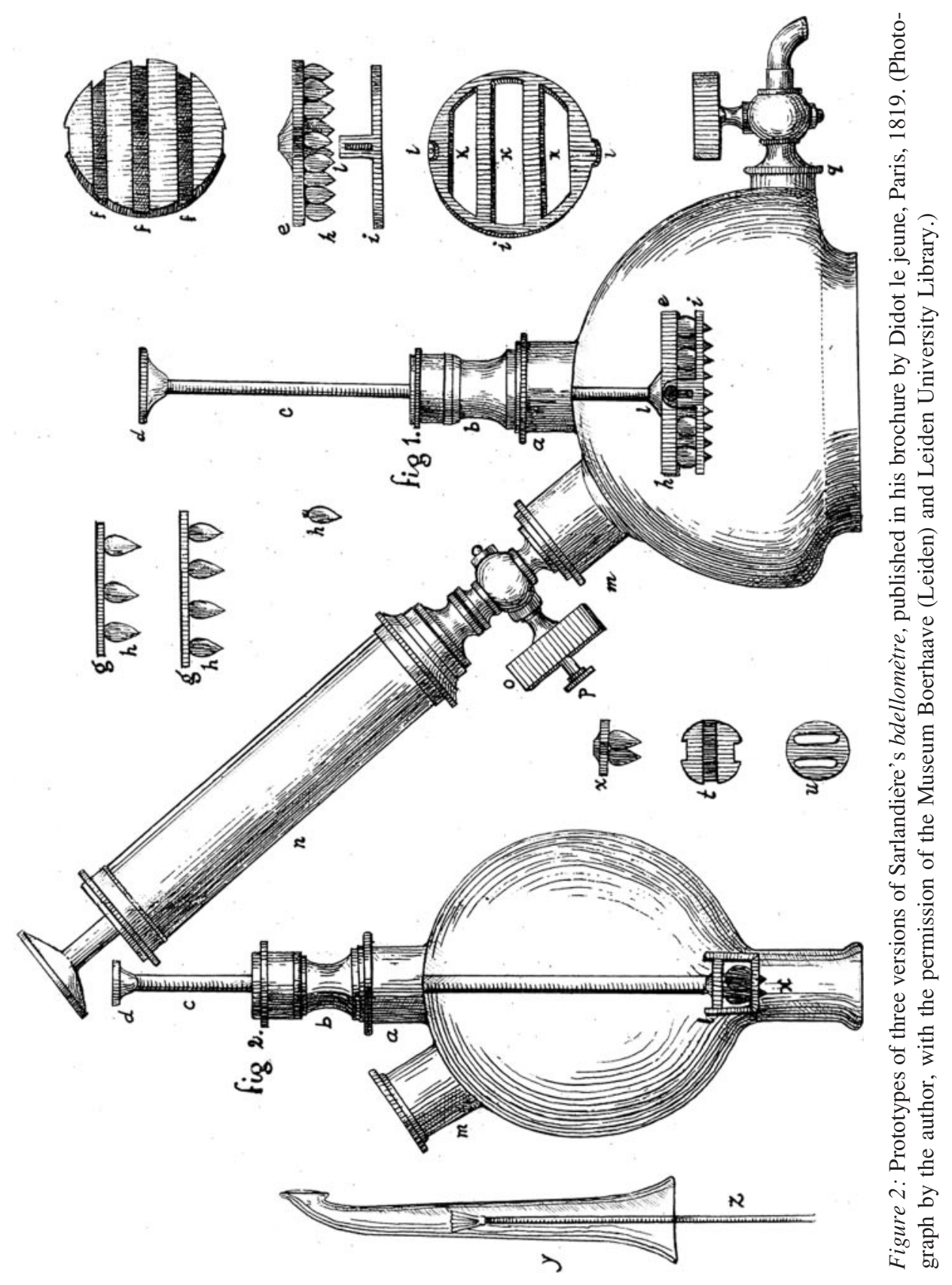




\section{Teunis Willem van Heiningen}

perforated in their central ends in order to give passage to the rod. The various scarificators, bearing a different number of lancets, are interchangeable. This enables the operator to produce wounds, differing in size and depth, according to need. By turning the knob of the lateral tube, air may be allowed into the ventouse and thus vary the amount of blood discharged from the wounds, while the pump is operated. The amount of blood flow depends on the degree of vacuum inside the instrument. The tap near the lower margin of the ventouse is meant to discharge its contents without the instrument being removed from the surface of the body. By operating the valve in the right way, one can tap off the overflow of blood from the ventouse. In this way it is also possible to operate on abscesses, treat empyemas, remove all kinds of alien bodies and relieve the chest, for example. Sarlandière cautions against the possible introduction of air into the wounds and into the blood vessels which have been cut. Of course, this warning also applies to regular bloodlettings.

In the epilogue of his brochure Sarlandière emphasized that the experiments proved that his bdellometre worked well and that several doctors, especially Jean-Baptiste Regnault, ${ }^{21}$ had already made successful use of it. But, of course, it was up to the users themselves to judge. However, he also had doubts about the general workability of his bdellometre and he wanted to bring these to the attention of his fellow practitioners. So, for example, in cases of abdominal diseases, such as gastritis, enteritis and peritonitis, preference should be given to the use of leeches.

In the 1820s, Sigismond Rohmer made a plea for the application of ventouses in general and for Sarlandière's bdellomètre in particular. ${ }^{22}$ It seemed to him that the use of ventouses had decreased since the beginning of the second half of the eighteenth century-a lamentable development-because the ventouse was a simple and reliable instrument, which could serve excellently in many diseases. In Rohmer's view Sarlandière's invention was the most ingenious design imaginable. Nevertheless, it had not achieved the fame it deserved. Regrettably, most surgeons and physicians were unable to operate it properly, perhaps due to laziness. Many physicians even showed an apparent aversion to its use, or at least a marked reluctance, thinking it was much easier to manipulate a couple of leeches, a job they could leave to the nurses, orderlies and servants. According to Rohmer, the late Professor Alexis Boyer ${ }^{23}$ had argued wrongly that most physicians,

\footnotetext{
${ }^{21}$ Jean-Baptiste Etienne Benoît Olive Regnault (1759-1836), chief physician at the Royal Hospital and personal physician to Louis XVIII.

${ }^{22}$ Sigismond Rohmer, Notice sur l'emploi des ventouses; en Allemagne et dans les Départemens François limitrophes de ce pays; ... présentée à l'Académie Royale de Médecine, Paris, Auguste Mie, s.d.; see also L Ch Roche and L J Sanson, Nouveaux éléments de pathologie médico-chirurgicale ou Précis théorique et pratique de médecine et de chirurgie, 4 vols, Paris, J-B Baillière, 1825-1828. They state that the instruments designed by Demours and Sarlandière are almost identical, although Sarlandière's largest version of the bdellometre is provided with a third cylindrical tube, with a tap near the lower margin of the cup, which is needed for discharging the blood. In
}

the view of Roche and Sanson this instrument will not work because, in order to evacuate the blood, air has to be let in, which is impossible, taking into account that the ventouse is almost filled with blood. Besides the cup will come loose as soon as the air starts to enter into it. It would be much more practical to take it off the skin. So in no way should one prefer the bdellomètre to the common ventouse. For that reason most physicians in France prefer common cups to Sarlandière's instruments if leeches are not available.

${ }^{23}$ Alexis Boyer (1757-1833), professor of pathology at the Faculté de Médecine of Paris and professor of surgery at the Hôpital de la Charité; member of the Académie de Médecine and of the Institut de France. Boyer served Napoléon I, Louis XVIII, Charles X and Louis-Philippe. 


\section{Jean-Baptiste Sarlandière's Mechanical Leeches}

out of ignorance, did not employ this useful instrument for blood letting, and that they possibly decided to use leeches instead of simple bleeding cups (ventouses), even though they knew that often less blood was discharged by cupping. Of course it was possible to apply more cups and to repeat the operation. Admittedly, the application of cups was laborious, because after each scarification a piece of paper or a small ball of cotton, drenched in alcohol, had to be lit in order to create a vacuum inside the ventouses. But the use of Sarlandière's bdellomètre was also laborious. Nevertheless, Rohmer was convinced of the advantages of this excellent instrument: an experienced ventouseur could easily serve several hospitals a day. Finally he observed that Boyer and other prominent French physicians deeply regretted that in France, from the 1760s, cupping had fallen more and more into disuse in favour of the use of leeches.

\section{Previous and Contemporary Inventions}

The author Lorenz Heister, who had served in the Dutch army for many years, claimed that Pieter van Musschenbroek, a Leiden scientist, deserved all the credit for having invented the double-acting pump, which the Amsterdam instrument maker Koops was the first to manufacture. ${ }^{24}$ In 1988 Barend Haeseker indicated that Ambroise Pare had previously invented an ingenious cylindrical mechanical device, provided with one sharp cutting wheel, operated by several cogwheels, and that Dominique Anel had invented a huge syringe with several appliances that would fit all types of wound. ${ }^{25}$

Heister himself had "invented", or at least "improved", several surgical instruments, including an automatic cylindrical scarificator which made sixteen little cuts in the skin. The 1755 edition of Heister's "superbly illustrated book" informs its readers that this device was ordered from England and that soon afterwards it was also manufactured in Leiden by Van Musschenbroek. Unfortunately Haeseker did not refer to another instrument, also discussed in Heister's 1755 edition, which bears a striking likeness to the instruments designed by Sarlandière. ${ }^{26}$

Because in the early 1800 s, since the development of the theory of inflammation, both the application of leeches and the practice of cupping appeared to have considerable disadvantages, "modern" physicians tried to find a substitute for them. This challenge was first taken up by English scientific instrument makers, because in England medicinal leeches had always been scarce. As a consequence of the great European military campaigns against France, the English scarificator found its way to Germany. In 1816 Professor Graefe of the University of Berlin-brother of Eduard Graefe, the author of a German treatise on Sarlandière's instrument-demonstrated the English instrument at a meeting of the Medizinisch-Chirurgische Gesellschaft zu Berlin. Not until several years later, in the course of 1819, was Sarlandière's prospectus published in Paris. Graefe

\footnotetext{
${ }^{24}$ L Heister, Heelkundige Onderwyzingen, waarin alles wat ter heling en genezing der uiterlyke gebreken behoort, 2 vols, Amsterdam, De Groot, 1755, vol. 2, pp. 1198-203.

${ }^{25}$ B Haeseker, 'Forerunners of mesh grafting machines: from cupping glasses and scarificators to
}

modern mesh graft instruments', Br. J. Plastic Surg. 1989, 41 (2): 209-12.

${ }^{26}$ Heister, op. cit., note 24 above, vol. 2, table 3, figure 5 . 


\section{Teunis Willem van Heiningen}

had several reasons for publishing the results of his own investigations. First of all, he wanted to inform his colleagues about the English invention. Secondly, he felt the need to compare this design with Sarlandière's instrument, and finally he wanted to point out the deficiencies of both instruments. Graefe concluded that Sarlandière's instrument was preferable to the English one, despite the French author's lack of precision and his evident unfamiliarity with what had aleady been published about the subject. If Sarlandière had known these facts, he would not have emphasized so strongly the originality and uniqueness of his own invention. None the less, he had been the first to succeed in developing adequate instruments in which the air pressure could be lowered to a desired degree, far better than in common bleeding cups. In Graefe's view, Sarlandière had wrongly claimed to have done pioneering work on the design of an instrument meant for drawing pus, of which there was already a long history. ${ }^{27}$

Another surgical instrument maker worth noting is John Weiss of London, who, probably in the 1820s, designed his "patent cupping apparatus", a separate scarificator, syringe and adjustable glass cup. It was an attempt to improve on already existing instruments, especially with respect to the incisions made by the lancets. ${ }^{28}$

Finally, the "snapper", a cubiform brass scarificator (Figure 3), was introduced on a large scale, not only in the Netherlands and Belgium, but also in Germany, and widely used in the second half of the nineteenth century, even in France. ${ }^{29}$ Examples of it can be found in the collections of the Museum Boerhaave (Leiden) and of the Museum voor Geschiedenis van de Geneeskunde (Ghent). Sarlandière's "invention" was embedded in a longer period of technological improvements, which were devised in response to new and increasingly specific demands from surgeons and physicians.

\section{The Competition of 1821}

Nine competitions were proposed at the annual general meeting of the Dutch Society of Sciences, held in May 1821. Seven of them-all dealing with technology (on the reclamation of land from the Lake of Haarlem, on the production of animal broth, on the physics of fire and on its technological applications, on industrial air pollution and its damaging effects on health and on the grafting of fruit trees) - were proposed by Martinus van Marum. The Society, for the moment highly interested in Sarlandière's sophisticated instrument, a "paragon of modern technology", wanted to know whether this device had already been perfected or if it was still susceptible of improvement. ${ }^{30}$ If the latter, the Society wished to be informed about the nature of these improvements. The verbatim text of the competition ran as follows:

\footnotetext{
${ }^{27}$ Eduard A Graefe, Dr. Sarlandière's Beschreibung eines neuen Blutsaugers, Berlin, Reimer, 1820.

${ }^{28} \mathrm{~J}$ Weiss, An account of inventions and improvements in surgical instruments, made by John Weiss, London, Longman, Reese, Orme, Brown \& Green, 1831, pp. 12-13, 146-7, 168-9.

${ }^{29}$ N P Adelon, et al., Dictionnaire de médecine, ou Répertoire général des sciences médicales, considérées
}

sous le rapport théorique et pratique, 30 vols, 2 nd ed., Paris, Béchet, 1844, vol. 28, pp. 125-35.

${ }^{30}$ Noord-Hollands Archief (Haarlem, The Netherlands), Archives of the Dutch Society of Sciences, NHA HMW 444-421.245; J G de Bruijn, Inventaris van de prijsvragen, uitgeschreven door de Hollandsche Maatschappij der Wetenschappen, 1753-1917, Haarlem, Hollandsche Maatschappij der Wetenschappen, Groningen, H D Tjeenk Willink, 1977, pp. 170-1. 


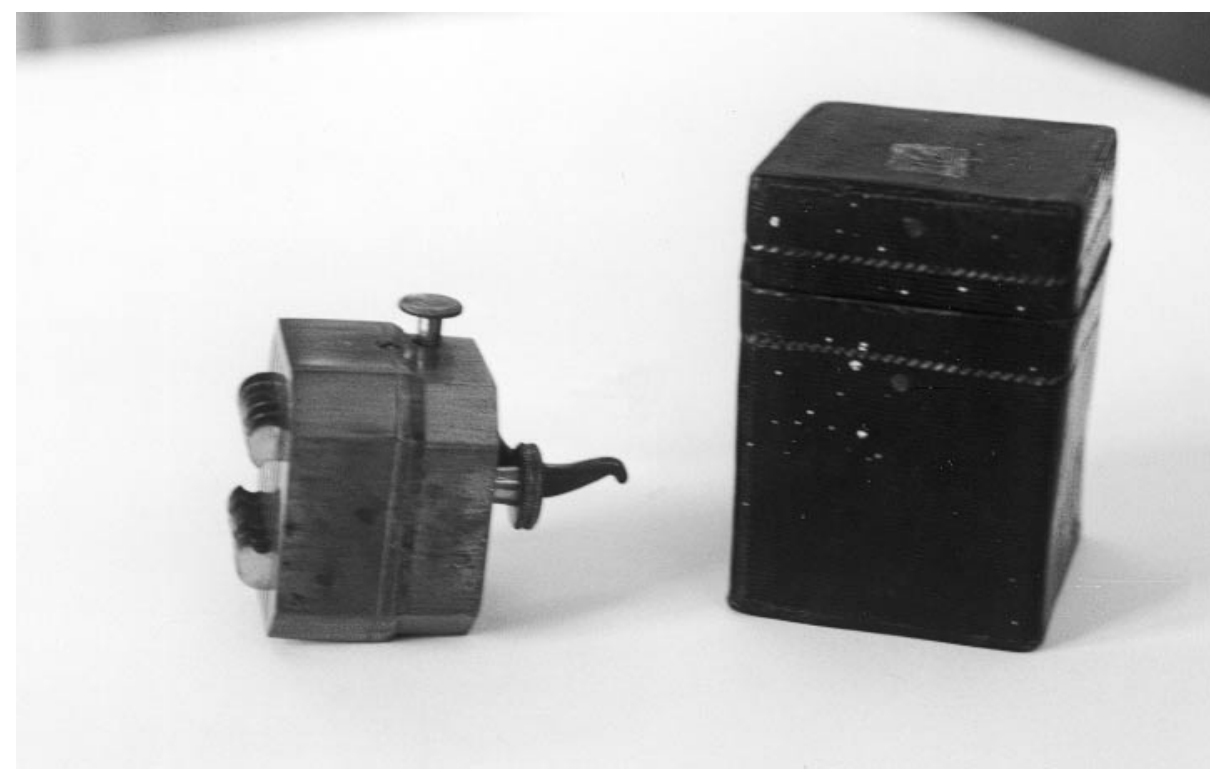

Figure 3: Example of a "snapper" in the collection of the Museum voor Geschiedenis van de Geneeskunde, Ghent, Belgium. (Photograph by the author with the permission of Professor Paul Kluyskens and Professor Isidoor Leusen, Ghent, Belgium.)

As nowadays leeches are more and more needed in order to heal diseases and because these animals are not always and everywhere available, the Society wants the following questions to be answered: has the instrument intended to replace leeches and called bdellometre, which has been invented by Dr. Sarlandière, already been brought to the highest possible degree of perfection and serviceability; or, if not, in what respect is it still defective? And how can these defects be remedied or completely avoided by improving its construction?

\section{The Entries}

The first entry was received shortly before 1 January 1825 . This document, adorned with Pope's maxim "It is with our judgments as with our watches, none goes just alike, yet each believes his own" was submitted anonymously, according to the rules of the Society, by Pieter Arnoldus van den Berg. ${ }^{31}$ By the end of 1825 the Society had received an improved text from Van den Berg, as well as a treatise written in French by Sarlandière, bearing the maxim "Inveni, Scrips, Judicate". ${ }^{32}$ In both rounds the jury consisted of J C B Bernard (professor of practical medicine at Leiden University),

\footnotetext{
${ }^{31}$ Pieter Arnoldus van den Berg was a surgeon and midwife in the town of Oudewater, The Netherlands.

${ }^{32}$ NHA HMW 444-421.245. Réponse à la question proposée par la Société hollandaise des sciences de Harlem, pour 1825: "L'instrument, pour suppléer au défaut des sangsues, inventé par le
}

Docteur Sarlandière et nommé Bdellomètre, est-il porté au plus haut degrée de perfection et d'utilité? Quels en sont encore les défauts? Comment pourraiton les prévenir, ou comment pourraient-ils être évités au moyen d'une meilleure construction?", manuscript (J-B Sarlandière), Paris, 1825, p. 4. 


\section{Teunis Willem van Heiningen}

H A van den Bosch (town physician, Rotterdam), J Logger (town surgeon, Leiden), C G Ontijd (town physician, The Hague), P de Riemer (army physician) and Martinus van Marum (secretary of the Society). ${ }^{33}$

\section{The Jury's Reports in the First Round (1825)}

Van den Bosch was the first to report. ${ }^{34}$ He concluded that the Dutch author was well informed about what had been written by foreign authors, but that unfortunately he was not acquainted with the academic treatise on leeches written by Albertus van Calcar (1823). ${ }^{35}$ Neither was he aware of the fact that large numbers of leeches were found in the neighbourhood of Hellevoetsluis and that these animals were even exported to England. In Van den Bosch's view, the author improved Sarlandière's bdellometre, by comparison with the illustration published in Van Onsenoort's Operatieve Heelkunde. ${ }^{36}$

All in all he was really impressed. The designs made by the Dutch author were quite different from Sarlandière's bdellomètre, although its basic principle was not changed. Van den Bosch knew that leeches have a strong aversion to human emanations and to excessive body heat. Furthermore this operation demanded constant supervision, because the extravasation had to be constantly removed. Finally many physicians disliked these animals. On the other hand, the new blood pumps (or Haemanthae) offered the advantage that they could be applied on wounds and abscesses as well, and operated much faster than applying a large number of leeches. In the opinion of Van den Bosch the blood pumps designed by the Dutch author were superior to the instruments invented by Sarlandière. He stated that these tools had to be preferred to leeches. The author's arguments were the more convincing if one considered the impending shortage of leeches in the Netherlands. Unfortunately the description given by the Dutch author did not accord completely with his drawings and he did not enter a prototype of his instrument. Van den Bosch confessed that he had not had the opportunity to evaluate the Dutch treatise completely, advising the Society not to award the prize until the author had brought the description into line with the illustrations and until he had proved that his instruments really had all the good qualities mentioned by him. Since Sarlandière's instrument was available in Paris, he suggested that the Society should order an example in order to examine its quality. He left the final judgement to the Society.

Bernard, the second member of the jury, noted that the Dutch author had called Sarlandière's instrument "an object completely deprived of coherence, being a too complicated construction, lacking the least solidity and unsuitable both in its components and in its assembly". It was in no way superior to the common ventouses, which implied that the instrument had not been developed to the highest degree of perfection and that its serviceability was still defective. The Dutch author was particularly disapproving because he thought that it did not even deserve the name it had been given, as it could

\footnotetext{
${ }^{33}$ NHA HMW 444-16: Notulenboek 1819-1839, p. 2242 .

${ }^{34}$ NHA HMW 444-421.245 R: H van den Bosch (Rotterdam) to M van Marum (Haarlem), 13 Feb. 1825 .
}

\footnotetext{
${ }^{35}$ Albertus van Calcar, Dissertatio medico inauguralis de hirudinis historia naturalis et uso medico, Leiden, L Herdingh et Filum, 1823.

${ }^{36}$ Van Onsenoort, op. cit., note 18 above, vol. 1, p. 171.
} 


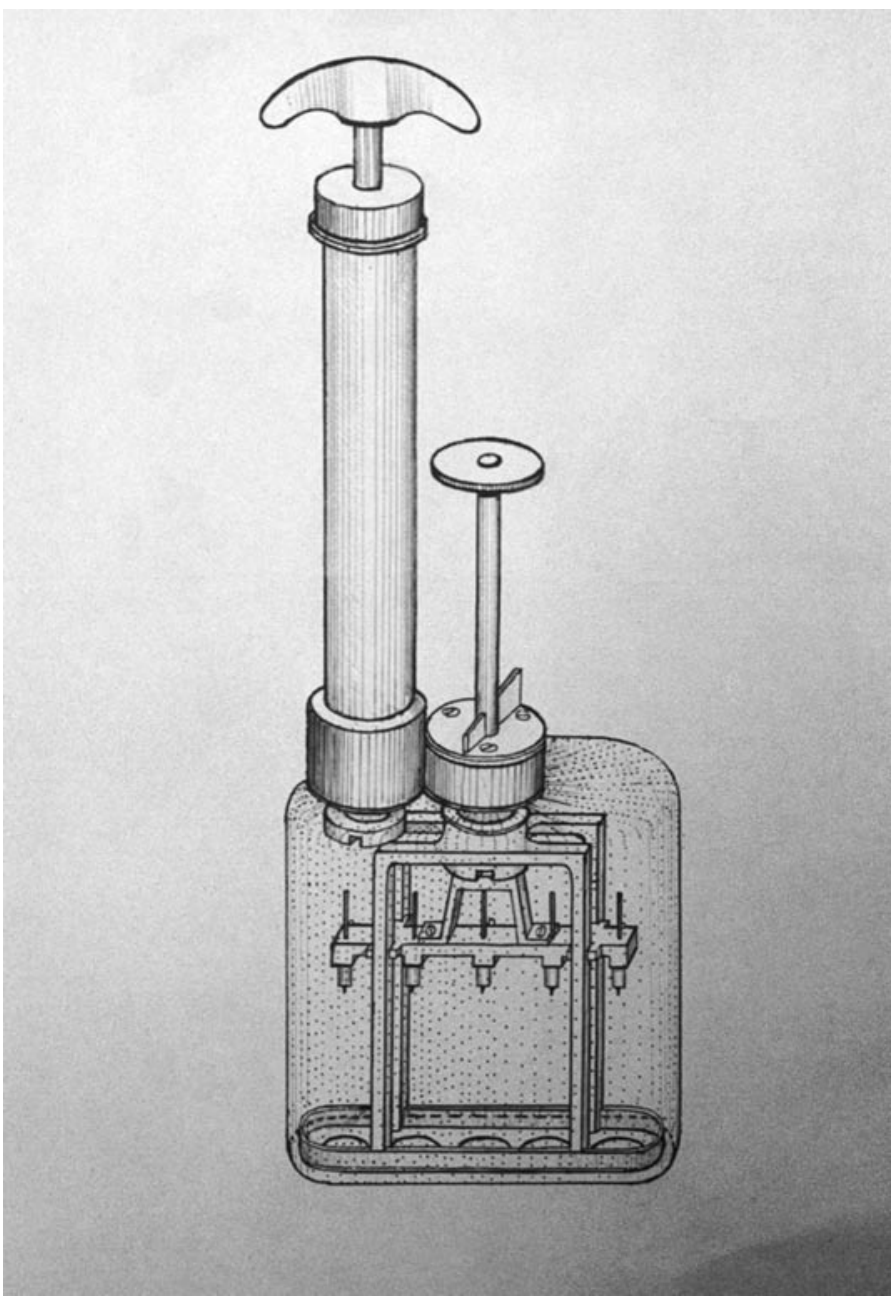

Figure 4: Blood pump designed by Pieter Arnoldus van den Berg (Oudewater, The Netherlands). This design was entered in the first round of the competition held by the Dutch Society of Sciences. Van den Berg added several designs to his treatise. (Photograph by the author, with the permission of the Noord-Hollands Archief, Haarlem, The Netherlands.)

only partially replace a leech. ${ }^{37}$ However, in Bernard's view the author did not succeed in proving that his own instrument surpassed Sarlandière's bdellomètre or that even common ventouses and leeches performed much better than the bdellomètre. The Dutch instruments could not be applied generally and they were not better than Sarlandière's

\footnotetext{
${ }^{37}$ NHA HMW 444-421.245 R: J Ch B Bernard (Brussels) to M van Marum (Haarlem), 14 April 1825.
} 


\section{Teunis Willem van Heiningen}

designs, although Bernard was willing to postpone his final judgement until after the author had presented prototypes of his instruments to the Society in order to be thoroughly examined.

Jacob Logger - the third member of the jury to report and a fierce adversary of the doctrine of Broussais-was clearly impressed by the technical ingenuity and by the author's style of writing. ${ }^{38} \mathrm{He}$ admired his thorough knowledge of the natural history of leeches, although he disagreed with several of his interpretations. For example, the author was right in his belief that the wounds caused by leeches keep on bleeding for longer than those made by a weapon or by a scarificator combined with a suction pump. ${ }^{39}$ However, the author was wrong to suggest that this continued bleeding, occurring after the leeches have come loose, lasts longer because these animals have produced a triangular wound and that such a wound keeps on bleeding more easily. Examining a wound caused by a three-sided stabbing weapon would prove the error of that belief. Logger agreed with the author's statement that a leech not only creates a vacuum, but that it can also locate exactly the arterial capillary networks. ${ }^{40}$ Logger knew that the suction practised by the leech provokes an accumulation of blood in the tissues underneath the wound and that the animal is able to search for small blood vessels before it starts biting. On the other hand the author was wrong to suppose that leeches continually move their teeth in order to maintain the underpressure. A leech does not possess teeth; its mouth is provided with three semilunar sawtoothed cartilages. Finally, Logger was amazed that the author clearly rejected Sarlandière's designs, although he had never set eyes on the instruments himself, nor did he carry out any experiments. Besides, he in no way proved that his instruments were superior to the ones invented by Sarlandière. Logger himself would never apply leeches or ventouses just like that in inflammations, in which the vital force is considerably increased. In his view it would be better to opt for a partial discharge of the abundance of blood beforehand in a different way. Furthermore Sarlandière's bdellomètre and the author's instrument were too complicated to be placed at the disposal of common country surgeons. All in all, this treatise could not be given a prize; at least, not until the author submitted specimens of the instruments designed by him to the Society for further examination.

Martinus van Marum, who had thought up the competition, and Ontyd and De Riemer did not submit reports because the three other members had been invited to do so. After the first round of the adjudication had been closed and its findings made public, the author of the Dutch treatise withdrew his contribution on the grounds that its text was not consistent with the illustrations. He promised to make the necessary corrections,

\footnotetext{
${ }^{38}$ NHA HMW 444-421.245 R: J Logger (Leiden) to $M$ van Marum (Haarlem), early spring 1825.

${ }^{39}$ Of course, the author was ignorant of the background of this phenomenon, i.e. its biochemical basis: the existence and nature of substances like heparin and hirudin.

${ }^{40} \mathrm{~J}$ Frédérik Montain, the elder, Des effets des différentes espèces d'évacuations sanguines artificielles (mémoire auquel la Société de Médecine de Bordeaux a décerné un médaille d'or dans sa séance publique du 30 août 1809, Lyons, J-M Barret,
}

1810, pp. 30-4: "Il seroit donc ridicule de penser, avec le crédule vulgaire, que les sangsues ont l'instinct de choisir le mauvais sang et de laisser celui qui est de bonne qualité; ces animaux n'ont pas d'autre instinct que l'envie de contenter leur avidité sanguinaire. L'irritation qui coincide avec l'issue du sang, ne peut être comparée à celle qui est produite par l'incision de l'instrument piquant et tranchant sur la peau, et le tissu membraneux des vaisseaux arteriels et veineux." 


\section{Jean-Baptiste Sarlandière's Mechanical Leeches}

and, in order to comply with the demand made by the Society, he offered to submit prototypes of his instruments. Unfortunately, he did not fulfil his obligations, although he submitted the improved text. ${ }^{41}$

\section{Was there a Second Round?}

Because Van den Berg, the author of the Dutch treatise, failed to keep his promises, the jury refused to judge the French entry until further notice. At a meeting held before the annual general meeting in 1826, the Society decided that the French author had no reason to complain about delay in the judgement of his entry, because in the course of 1825 it had decided not to continue the competition. Unfortunately it did not notify him of that decision, and not a word was said about this affair at the annual general meeting of 20 May 1826 or in the following meetings. ${ }^{42}$

\section{Did Sarlandière Improve his Design made in 1817-1819?}

In the opening sentences of his treatise of nine pages, sent to the Dutch Society, and largely identical to his publication of 1819 , Sarlandière emphasized that his invention had been designed in order to solve the problems resulting from the increasing shortage of leeches. As it was possible with this instrument to puncture and to suck alternately, its operation really approached the way leeches operate. On page 4 the author generously admitted that in all abdominal disorders, like gastritis, enteritis and peritonitis, leeches apparently worked better than his bdellomètres.

In striving for further simplification and perfection of his instrument according to the demands of the Society, Sarlandière designed the bdellon (Figure 5, figs 17 to 20). This new instrument, made of brass or silver, enabled fast and simple discharges of blood. It consisted of twelve cylindrical tubes, in each of which a piston could be moved upward and downward. The lower end of each piston bore its own scarificator, the lower end of each cylinder was provided with a small valve, opening when the piston was pushed downwards and closing when it was pulled upwards. The upper ends of the twelve pistons were fixed to a circular metal disc, on the centre of which a thin rod was mounted, carrying a ring. The lower ends of the cylinders were mounted on a second circular disc, with triangular openings through which the arcuated tips of the pistons could pass precisely. When the upper ring was pushed downwards, the valves of the pistons would close and the razor-sharp triangular ends of the pistons penetrate the skin and the subcutaneous tissues. After the wounds were made, the pistons were pulled upwards, and the blood would begin to flow into the cylinders. When the pistons were pushed downwards for the second time, the blood was discharged through the outlet valves. The ring-shaped saucer fixed onto the edge of the lower circular plate enabled the surgeon to prevent his patients from becoming stained with their own blood. In Sarlandière's view this was really the most simple, compact and solid instrument that could be produced by mechanical engineering. Sarlandière even designed several versions of his bdellon. The cylinders of the larger compound instrument are two pouces $(5.41 \mathrm{~cm}$ ) high and have

${ }^{41}$ NHA HMW 444-16: Notulenboek 1819-1839, pp. 2252-253, 2260.
${ }^{42}$ NHA HMW 444-16: Notulenboek 1819-1839, pp. 2260, 2269, etc. 


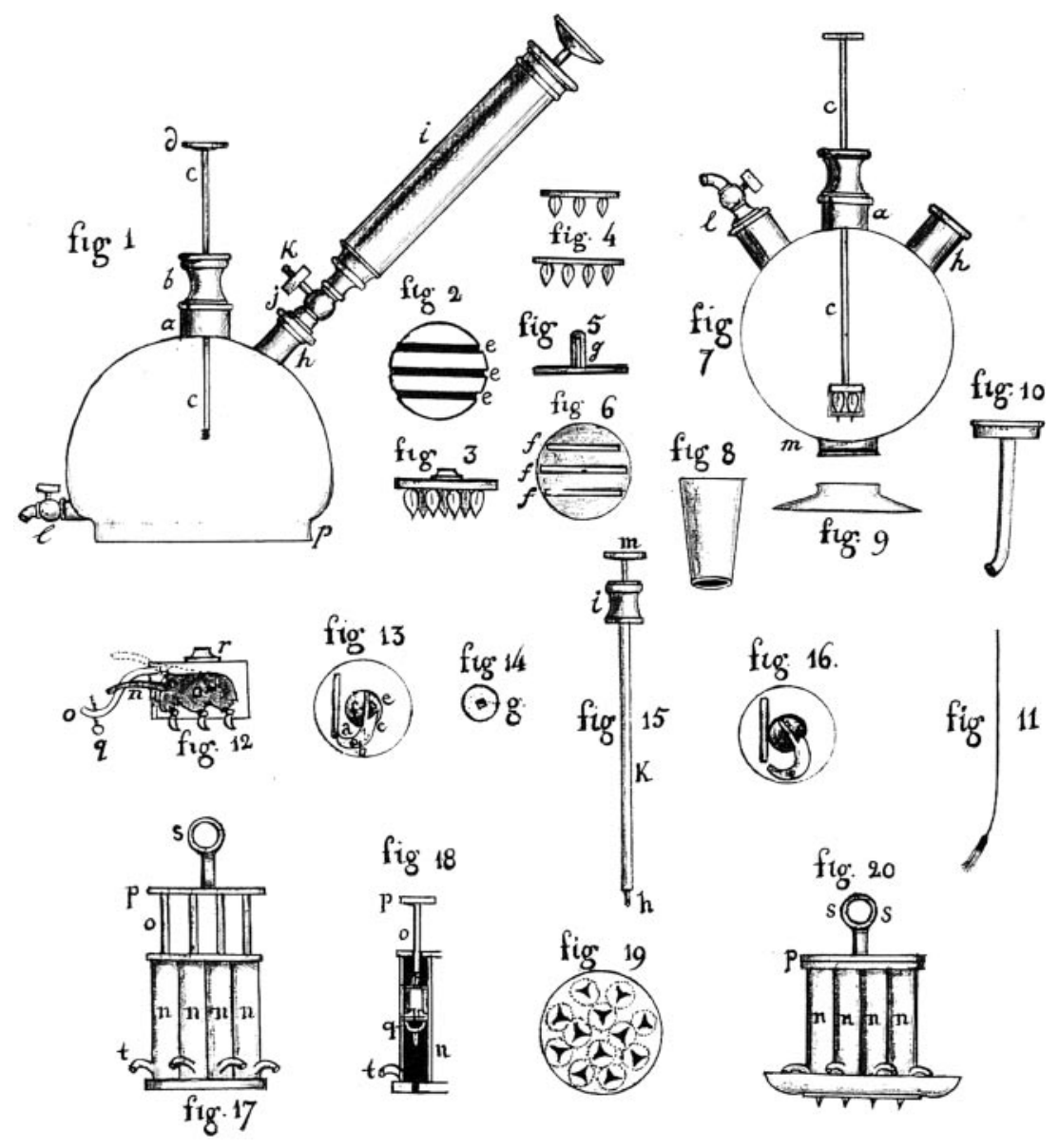

Figure 5: Designs entered by Jean-Baptiste Sarlandière late 1825. The bdellons discussed in this article are represented by the numbers 17 to 20. (Photograph by the author with the permission of the Noord-Hollands Archief, Haarlem.)

a diameter of 5 lines $(1.53 \mathrm{~cm})$. The cylinders of the smaller one are one pouce high $(2.71 \mathrm{~cm})$ and 1.5 lines $(0.40 \mathrm{~cm})$ in diameter. ${ }^{43}$

In spite of Sarlandière's efforts, the jury did not award his entry a prize. As has been indicated, this outcome was most probably due to the fact that the Dutch entrant had not sent the instruments he had promised. Besides, the need for substituting leeches by an instrument was felt less in the Netherlands than in most of the surrounding countries. Finally the secretary never ordered specimens of Sarlandière's instruments from Paris, because the job of sending these instruments was explicitly the author's. As a consequence Sarlandière's entry passed into oblivion.

\footnotetext{
${ }^{43} 1$ pouce (eighteenth century, French) measures $2.71 \mathrm{~cm}$, while 1 inch measures $2.54 \mathrm{~cm} .1$ pouce measures 10 lignes.
} 


\section{Jean-Baptiste Sarlandière's Mechanical Leeches}

\section{Epilogue: The Decline of Broussais's Popularity}

In 1828 the Dutch Society of Sciences held a similar competition on the usefulness or not of the application of large numbers of leeches in all kinds of diseases. ${ }^{44}$ In the eyes of the jury the only competitor-G J Pool (Amsterdam), who entered his treatise in 1831 - discussed this subject with too little subtlety, starting his thesis from an oversimplified and prejudiced point of view. The fact that in doing so he gained the disapproval of the jury is less important than that the various reports indicate that the members of the Society were without exception fierce opponents of Broussais's doctrine of bleeding. As a consequence, it was impossible to award Pool the medal and likewise it shows that there was no longer an urgent need to accept Sarlandière's designs.

In 1829 G C B Suringar's prizewinning book on Broussais, entitled Geschied- en oordeelkundige verhandeling over het leerstelsel van den Franschen geneesheer Broussais (Historical and Geographical Examination of the Teaching of the French Doctor, Broussais), was published in Amsterdam. ${ }^{45}$ Although in France Broussais had many followers, they were far fewer in England, Italy and Germany. In the Netherlands there was quite a difference between the southern provinces, which in 1831 were to become the kingdom of Belgium, and the northern provinces, remaining part of the kingdom of the Netherlands. Broussais found most of his adherents in the future country of Belgium, whereas those in the north were less enthusiastic. In late 1837 C G Ontyd, personal physician to William I of the Netherlands, repeated that Broussais had now lost most of his followers. ${ }^{46}$ The journal Tijdschrift ter Bevordering der Physiologische Genees- en Heelkunde, founded in 1827, which supported Broussais's views, lasted a mere three years, folding in 1831. Suringar did not reject Broussais's ideas completely, because like the rest of his colleagues he was convinced that over the previous twelve to fifteen years the diseases prevalent in Europe had become more and more epidemic and of an inflammatory nature, which, of course, prepared the way for Broussais and his doctrine. Suringar himself advocated the need for a scrupulous evaluation of the use of leeches, as an increasing number of physicians had decided to return to the application of these animals. However, in his view it was still too premature to make a final decision.

Over the next few years the advocates and the adversaries of Broussais kept on discussing the pros and cons of bloodletting in all kinds of diseases. In France its advocates were in the majority. Among the ardent supporters of bloodletting in yellow fever cases were Jean Devèze, Antoine Dalmas and Jean-André Rochoux, all physicians with experience in regions haunted by yellow fever. ${ }^{47}$ They unanimously considered this treatment

\footnotetext{
${ }^{44}$ Graefe, op. cit., note 27 above, p. 210; NHA HMW 444-429.324 R.

${ }^{45}$ G C B Suringar, Geschied-en oordeelkundige verhaldeling over het leerstelsel van ... Broussais, Amsterdam, G C Sulpke, 1829, pp. 12-35; G A Lindeboom, 'De leer van Broussais in Nederland', Nederlandsch Tijdschrift voor Geneeskunde, 1955, 99: 955-63, 1240-5; See also Biographisches Lexicon der hervorragenden Aerzte, op. cit., note 8 above, vol. 1, pp. 616-17.

${ }^{46}$ C G Ontyd, 'Proeve over den tegenwoordigen staat der geneeskunst', in Nieuwe Verhandelingen der
}

\author{
Eerste Klasse van het Koninklijk Nederlandsch \\ Instituut van Wetenschappen, Letterkunde en Schoone \\ Kunsten, 13 vols, Amsterdam, C G Sulpke, 1838, vol. \\ 7, pp. 47-128. \\ ${ }^{47}$ Jean Devèze (1746-1826) studied medicine in \\ Bordeaux and Paris, and served as a physician in \\ Santo Domingo, where he founded a hospital. In 1793 \\ Devèze fled to Philadelphia, where he witnessed the \\ yellow fever epidemic of that year and wrote a book \\ on it. In 1804 he took his doctoral degree with a \\ second version of his book, entitled Sur la fiève \\ jaune. Antoine Dalmas (1757-1830) was a naval
}




\section{Teunis Willem van Heiningen}

excellent, especially during the first days of the disease. According to Augustin Pierre Isidore de Polinière, all medical doctors employed in the Val-de-Grâce were at the time convinced that yellow fever was a gastroenteritis of the worst kind. ${ }^{48}$

\section{Conclusions}

The obvious belief of Dutch physicians that over the previous decades the character of diseases prevailing in the Netherlands had become more and more inflammatory may have facilitated the interest of the Dutch medical world-and as a consequence also of the Dutch Society of Sciences-in Sarlandière's instruments. The attention of the foreign medical world turned to this subject by the publicizing of this competition in the French version of the annual programme which was sent as a matter of course to all foreign members of the Society as well as to its associated scientific societies and academies abroad. Sarlandière's invention was not unique. It did not come out of the blue. It belongs in a series of inventions made between the early eighteenth century and the mid-nineteenth century, and the Dutch Society of Sciences already had a tradition in the field of technology and mechanical engineering. But the results of the competition were unsatisfactory. Van den Berg's entry did not fulfil entirely the demands made by the jury: instead of evaluating thoroughly Sarlandière's instruments, he presented a design made by himself without indicating any possible improvements, as had been demanded by the Society. Secondly, he should have submitted specimens of the instruments manufactured after his designs, but he did not.

The Society did not receive Sarlandière's treatise until late December 1825. Furthermore the drawings attached to it proved to be almost identical to the ones attached to Sarlandière's brochure, and it was not accompanied by the instruments represented in the drawings. As a consequence of the negligence and unwillingness of Van den Berg, the French treatise was never properly adjudicated. From a comparison of Sarlandière's brochure of 1819 with his essay of 1825 , it is obvious that the French author really did improve his original designs and that he added a new and simpler instrument. So, if his treatise had been assessed and if the jury had had the opportunity to check the quality of the various instruments, it might have decided to award the prize to his entry. The disappointing outcome of this contest may also have resulted from the fact that the doctrine of Broussais never found general acceptance in the Netherlands, except in the southern provinces (Zeeland and North Brabant) and those that became part of the kingdom of Belgium. Nevertheless, Sarlandière's instruments did find some acceptance in the Netherlands, although much less than in France and other neighbouring countries.

physician, serving in several regions where yellow fever epidemics were frequent. He was the author of Recherches historiques et médicales sur la fiève jaune, Paris, Marchant, 1805. He died in the United States. Jean-André Rochoux (1787-1852) was a member of the Section Médicale de l'Encyclopédie Méthodique. In 1821 he was appointed member of the Committee for the investigation of the yellow fever epidemic in Barcelona. Rochoux served as a physician at the Infirmerie de Bicêtre in Paris. He was a member of the Académie Royale de Médecine.

${ }^{48}$ A P I Polinière, Etudes cliniques sur les émissions sanguines artificielles, 2 vols, Paris, Baillière, 1827, vol. 1, pp. 168-9, 405. A physician, Polinière was appointed director of the Charite at Lyons. In 1826, the Société Académique de Marseille presented him with a prize for this book. 